\title{
Effect of dietary nitrogen content and intravenous urea infusion on ruminal and portal-drained visceral extraction of arterial urea in lactating Holstein cows
}

\author{
N. B. Kristensen, ${ }^{1}$ A. C. Storm, and M. Larsen \\ Department of Animal Health and Bioscience, Faculty of Agricultural Sciences, Aarhus University, DK-8830 Tjele, Denmark
}

\begin{abstract}
Urea extraction across ruminal and portal-drained visceral (PDV) tissues were investigated using 9 rumencannulated and multi-catheterized lactating dairy cows adapted to low-N (12.9\% crude protein) and high-N ( $17.1 \%$ crude protein) diets in a crossover design. The interaction between adaptation to dietary treatments and blood plasma concentrations of urea was studied by dividing samplings into a 2.5 -h period without urea infusion followed by a 2.5 -h period with primed continuous intravenous infusion of urea $(0.493 \pm 0.012$ $\mathrm{mmol} / \mathrm{kg}$ of BW per $\mathrm{h}$ ). Cows were sampled at $66 \pm$ 14 and $68 \pm 12 \mathrm{~d}$ in milk and produced $42 \pm 1$ and 36 $\pm 1 \mathrm{~kg}$ of milk/d with the high-N and low-N diets, respectively. The arterial blood urea concentration before urea infusion was 1.37 and $4.09 \pm 0.18 \mathrm{mmol} / \mathrm{L}$ with low- $\mathrm{N}$ and high- $\mathrm{N}$, respectively. Dietary treatment did not affect the urea infusion-induced increase in arterial urea concentration $(1.91 \pm 0.13 \mathrm{mmol} / \mathrm{L})$. Arterial urea extraction across the PDV and rumen increased from 2.7 to $5.4 \pm 0.5 \%$ and from 7.1 to $23.8 \pm 2.1 \%$ when cows were changed from high-N to low-N, respectively. Urea infusion did not decrease urea extractions, implying that urea transport rates were proportional to arterial urea concentrations. Urea extraction increased more across the rumen wall than across the total PDV for low-N compared with high-N, which implies that a larger proportion of total PDV uptake of arterial urea is directed toward the rumen with decreasing $\mathrm{N}$ intake. The ruminal vein - arterial (RA) concentration difference for ammonia increased instantly (first sampling 15 min after initiation of infusion) to the primed intravenous infusion when cows were adapted to the low- $\mathrm{N}$ diet. The RA difference for ammonia correlated poorly to the ventral ruminal concentration of ammonia $(\mathrm{r}=$ 0.55). Relating the RA difference for ammonia to a function of both ruminal ammonia concentration and the RA difference for urea markedly improved the fit
\end{abstract}

Received January 9, 2010.

Accepted February 26, 2010.

${ }^{1}$ Corresponding author: nbk@agrsci.dk $(\mathrm{r}=0.85)$, indicating that a large fraction of ammonia released to the ruminal vein is absorbed from an epithelial ammonia pool not in equilibrium with the ventral ruminal ammonia pool. Changing cows from high-N to low-N affected the relative blood urea clearance by kidneys and PDV. The clearance by the kidneys decreased from 41 to $27 \pm 2 \mathrm{~L} / \mathrm{h}$ and the clearance by the PDV increased from 52 to $105 \pm 12 \mathrm{~L} / \mathrm{h}$ when the diet was changed from high-N to low-N. In conclusion, urea transport across gut epithelia in cattle is adapting to $\mathrm{N}$ status and driven by mass action. Data are commensurable with a model for urea transport across gut epithelia based on regulated expression or activity of facilitative urea transporters.

Key words: dairy cow, urea recycling, ammonia absorption, dietary crude protein

\section{INTRODUCTION}

The digestive strategy of ruminants affects fundamental mechanisms of protein digestion and metabolism related to overall $\mathrm{N}$ efficiency. Amino acid deamination in the forestomachs releases ammonia that is absorbed to the blood (Reynolds and Kristensen, 2008), and high recovery of duodenal purine bases in urine (Vagnoni et al., 1997; Gonzalez-Ronquillo et al., 2003) imposes $\mathrm{N}$ losses associated with microbial fermentation. The actual loss is directed by the difference in purine content between feed and ruminal outflow because dietary purines are largely degraded in the rumen (McAllan and Smith, 1973). The absorption of ammonia from deaminated amino acids and the inevitable loss of $\mathrm{N}$ in urinary purines could, in theory, be counterbalanced by the ability of the ruminant to recycle and utilize urea and other $\mathrm{N}$ compounds transported from blood to the rumen. The obvious way to make use of this ability of the ruminant digestive system would be to adjust dietary $\mathrm{N}$ intake based on the amount of recycled $\mathrm{N}$ to the rumen and replace dietary $\mathrm{N}$ with recycled $\mathrm{N}$. Previous studies have clearly demonstrated that cattle respond to decreasing dietary $\mathrm{N}$ intake by changing the proportion of endogenous urea recycled to the gut com- 
pared with the proportion excreted in urine (Kennedy et al., 1981; Marini and Van Amburgh, 2003; Wickersham et al., 2008). Also, in dairy cows fed low $\mathrm{N}$ diets, the proportion of urea recycled to the gut is higher than the proportion excreted in urine (Røjen et al., 2008; Røjen and Kristensen, 2009). However, even though a larger proportion of the total entry rate of urea was recycled to the gut, recycling in absolute amounts did not increase in any of these previous studies in which $\mathrm{N}$ status was manipulated by dietary interventions.

There exists a mismatch between the general agreement that urea transport across gut epithelia is directed by mass action (primarily based on data from sheep and goats; Harmeyer and Martens, 1980; Sunny et al., 2007) and the curvilinear relationship between arterial urea concentration and the extraction of arterial urea across the portal-drained viscera (PDV) in cattle showing declining urea extraction with increasing blood urea concentration (Røjen et al., 2008; Calsamiglia et al., 2010). Two hypotheses can explain the observed relationship between epithelial urea supply and transport in cattle: A) mass action driven transport combined with downregulation of epithelial urea permeability with increasing $\mathrm{N}$ status, and $\mathrm{B}$ ) fixed transport capacity for urea across the epithelia independent of blood urea supply to the epithelium. Changes in expression or activity of urea transporters facilitating the transepithelial transport of urea is a mechanism by which changes of urea transport postulated in hypothesis A could be explained (Stewart et al., 2005; Simmons et al., 2009). The transporters expressed or activated in response to manipulation of dietary $\mathrm{N}$ :carbohydrate ratio remain unidentified and if urea transport is facilitated only by constitutive proteins with low transport capacity, hypothesis B could also explain the observed lack of changes in urea transport with changes in $\mathrm{N}$ status.

The objective of the present experiment was to investigate the ruminal and PDV extraction of arterial urea at low and high $\mathrm{N}$ intakes and to investigate the interaction between dietary $\mathrm{N}$ status and blood urea level on urea extraction and ammonia absorption. The hypotheses tested were hypothesis $\mathrm{A}$ versus B. If reduced $\mathrm{N}$ intake increased urea extraction and the extraction ratio was maintained with short-term increase in arterial urea concentration by infusion it would point toward hypothesis A. Otherwise, if cows maintained similar PDV and ruminal uptake rates of urea and decreased extraction ratios of arterial urea with urea infusion it would point toward hypothesis B.

\section{MATERIALS AND METHODS}

The present experiment complied with Danish Ministry of Justice Law no. 382 (June 10, 1987), Act no.
726 (September 9, 1993), concerning experiments with animals and care of experimental animals.

\section{Animals and Feeding}

Nine second-parity Danish Holstein cows were implanted with ruminal cannulas and permanent indwelling catheters in an artery, mesenteric vein, hepatic portal vein, and hepatic vein prepartum as described previously (Kristensen et al., 2007; Larsen and Kristensen, 2009). An additional catheter was implanted in the right ruminal vein by dissecting a small branch of the right ruminal vein on the right face of the caudoventral blind sac. The catheter was passed dorso-cranially along the ascending right ruminal vein following the ventral coronary groove, and the tip was placed in the right ruminal vein 5 to $10 \mathrm{~cm}$ cranial to the bifurcation with the ascending branch. In a few cows, the catheter tip was located in the ascending branch within the coronary groove. The ruminal vein catheter was made of silicone tubing (Saint Gobain STHT-C040-0F, $1.02 \mathrm{~mm}$ i.d., $2.18 \mathrm{~mm}$ o.d.; Colly FlowTech AB, Kista, Sweden). Several cuffs of silicone glue were placed 35 to $50 \mathrm{~cm}$ from the catheter tip to aid in fixing the catheter.

Cows were transferred from a previous study ending on 30 DIM and fed a mixture of the 2 experimental diets for $8 \mathrm{~d}$, on average, before being allocated to the experimental diets of the present study. Cows were randomly allocated to 2 experimental diets in a crossover design (balanced for 8 cows) with 21-d periods. The dietary treatments were low $\mathrm{N}(12.9 \% \mathrm{CP})$ and high N (17.1\% CP; Table 1). Cows were sampled on d 14 of each period. Diets were offered ad libitum (5\% orts as minimum) and fed in 3 equally sized portions at 0800 , 1600 , and $2400 \mathrm{~h}$. Cows were milked at 0600, 1400, and $2200 \mathrm{~h}$.

\section{Experimental Samplings}

Cows were fitted with a temporary jugular catheter (1.02 mm i.d., $1.78 \mathrm{~mm}$ o.d., Tygon, S-54-HL, Buch \& Holm A/S, Herlev, Denmark) approximately $2 \mathrm{~h}$ before first blood sampling. The catheter was inserted $15 \mathrm{~cm}$ into the right external jugular vein by percutaneous venipuncture using a hypodermic needle $(2.5 \times 110$ $\mathrm{mm}$, Mediplast AB, Malmö, Sweden) following shaving, skin disinfection, and subcutaneous injection of $5 \mathrm{~mL}$ of xylocaine (Lidocaine $20 \mathrm{mg} / \mathrm{mL}$, AstraZeneca A/S, Albertslund, Denmark). The catheter was secured by a skin suture between 2 cuffs (5- to 8-mm-long pieces of Tygon blue/yellow pump tubing, Buch \& Holm A/S) slid over the catheters using a pair of hemostats after removal of the hypodermic needle. 
Table 1. Dietary composition ( $\mathrm{g} / \mathrm{kg}$ of DM unless otherwise noted) of low- and high-N diets

\begin{tabular}{|c|c|c|}
\hline Item & Low $\mathrm{N}$ & High $\mathrm{N}$ \\
\hline \multicolumn{3}{|l|}{ Ingredient } \\
\hline Corn silage ${ }^{1}$ & 299 & 299 \\
\hline Grass clover silage $^{2}$ & 250 & 250 \\
\hline Barley, rolled & 298 & 298 \\
\hline Dehulled soymeal & - & 120 \\
\hline Soyhulls & 96 & - \\
\hline Molasses, cane & 24 & - \\
\hline Mineral and vitamin premix ${ }^{3}$ & 10 & 10 \\
\hline PFAD fat ${ }^{4}$ & 10 & 10 \\
\hline $\mathrm{NaHCO}_{3}$ & 5.0 & 5.0 \\
\hline $\mathrm{Ca}\left(\mathrm{H}_{2} \mathrm{PO}_{4}\right)_{2}$ & 3.0 & 0.5 \\
\hline $\mathrm{CaCO}_{3}$ & 2.5 & 5.0 \\
\hline $\mathrm{Na}_{2} \mathrm{SO}_{4}$ & 2.0 & 2.0 \\
\hline Chromium (III) oxide & 1.0 & 1.0 \\
\hline \multicolumn{3}{|l|}{ Nutrient } \\
\hline $\mathrm{DM}, \mathrm{g} / \mathrm{kg}$ & 420 & 427 \\
\hline Ash & 67 & 61 \\
\hline $\mathrm{CP}$ & 129 & 171 \\
\hline Crude fat & 39 & 38 \\
\hline $\mathrm{NDF}$ & 282 & 245 \\
\hline \multicolumn{3}{|l|}{ Calculated nutrient composition } \\
\hline Rumen-degraded $\mathrm{CP}^{5}$ & 84 & 116 \\
\hline MP (NorFor AAT $)^{5}$ & 66 & 92 \\
\hline $\mathrm{NE}_{\mathrm{L}},{ }^{5} \mathrm{MJ} / \mathrm{kg}$ of $\mathrm{DM}$ & 6.6 & 7.0 \\
\hline
\end{tabular}

${ }^{1}$ Chemical composition of corn silage: DM, $33.6 \%$; ash, $2.9 \%$ of DM; CP, $8.6 \%$ of DM; crude fat, $2.2 \%$ of DM; NDF, $32.7 \%$ of DM; starch, $31.7 \%$ of DM (Eurofins Steins Laboratorium A/S, Holstebro, Denmark).

${ }^{2}$ Chemical composition of grass clover silage: DM, $41.4 \%$; ash, $8.3 \%$ of $\mathrm{DM}$; CP, $16.2 \%$ of DM; crude fat, $4.4 \%$ of DM; NDF, $32.6 \%$ of DM; starch, $1.0 \%$ of DM (Eurofins Steins Laboratorium A/S).

${ }^{3}$ Premix containing (per $\mathrm{kg}$ ): $180 \mathrm{~g}$ of Ca, $4 \mathrm{~g}$ of P, $65 \mathrm{~g}$ of $\mathrm{Mg}, 80 \mathrm{~g}$ of $\mathrm{Na}, 30 \mathrm{~g}$ of S, $693 \mathrm{kIU}$ of vitamin A, $146 \mathrm{kIU}$ of vitamin D, 4,620 mg of $\alpha$-tocopherol, 3,080 $\mathrm{mg}$ of $\mathrm{Mn}, 693 \mathrm{mg}$ of $\mathrm{Cu}, 19 \mathrm{mg}$ of Co, 3,460 $\mathrm{mg}$ of $\mathrm{Zn}, 173 \mathrm{mg}$ of I, and $38.5 \mathrm{mg}$ of Se (VM 1; Vitfoss, Gråsten, Denmark).

${ }^{4}$ Palm fatty acid distillate (Scanfedt A/S, Frederica, Denmark).

${ }^{5}$ Calculated using the Nordic Feed Evaluation System (NorFor; www. norfor.info).

Continuous infusion of $p$-aminohippuric acid (pAH; $32.0 \pm 0.5 \mathrm{mmol} / \mathrm{h}$ ) into the mesenteric vein was initiated at least $60 \mathrm{~min}$ before the first blood sampling using silicone tubing (\#39339, $1 \mathrm{~mm}$ i.d., $3 \mathrm{~mm}$ o.d.; Ole Dich Instrumentmakers, Hvidovre, Denmark) and a peristaltic pump (type 110-B; Ole Dich Instrumentmakers). The infusate was a $175 \mathrm{~m} M$ solution of $\mathrm{pAH}$ (4-aminohippuric acid 99\%, Acros, Geel, Belgium) adjusted to $\mathrm{pH}$ 7.4, filtered (Filter Top PES membrane $0.22 \mu \mathrm{m}$, Techno Plastic Products AG, Trasadingen, Switzerland), and autoclaved.

At approximately $1045 \mathrm{~h}, 25 \mathrm{~g}$ of deuterium oxide $\left(\mathrm{D}_{2} \mathrm{O}\right.$, Aldrich 99.9\%; Sigma-Aldrich Chemie $\mathrm{GmbH}$, Steinheim, Germany) dissolved in $500 \mathrm{~mL}$ of water was added to the ruminal fluid pool using a peristaltic pump and infused over 2 min simultaneously with vigorous manual mixing of ruminal contents in situ. Another 500
$\mathrm{mL}$ of water was infused after the $\mathrm{D}_{2} \mathrm{O}$ solution to rinse $\mathrm{D}_{2} \mathrm{O}$ from the infusion tubing.

At $1245 \mathrm{~h}$, a primed continuous infusion of urea into the jugular vein was initiated. The priming dose was $0.782 \pm 0.006 \mathrm{mmol}$ of urea $/ \mathrm{kg}$ of BW, and the infusion rate was $0.493 \pm 0.012 \mathrm{mmol} / \mathrm{kg}$ of BW per h. The urea infusate was a 1,295 mmol $/ \mathrm{kg}$ solution of urea (Urea p.a. \#08487, Merck KGaA, Darmstadt, Germany) filtered and infused as described for pAH. The infusate was used within $3 \mathrm{~d}$ after preparation and stored at $4^{\circ} \mathrm{C}$. The priming dose of urea was injected within 3 min and the continuous infusion initiated immediately thereafter. Preliminary experiments had shown that the selected urea infusion rate would increase the arterial concentration of cows fed the low- $\mathrm{N}$ diet to approximately the level of cows fed the high-N diet without infusion and thereby enable investigations of the effects of dietary adaptation with similar arterial urea concentrations.

Regular blood samples were obtained every $30 \mathrm{~min}$ from $1000 \mathrm{~h}$ to $1500 \mathrm{~h}$ (10 sets) from the artery, portal vein, hepatic vein, and ruminal vein. Small-volume blood samples from only artery, portal vein, and ruminal vein were obtained $3,6,9$, and 12 min after intraruminal $\mathrm{D}_{2} \mathrm{O}$ dosing. The first regular blood sample after initiation of urea infusion was collected 15 min after initiation of infusion.

Before blood sampling, catheters were primed by drawing a minimum of 2 times the catheter volume into a blank syringe and discarding the blood. Every hour, blood samples were collected for blood gas and oximetry measurements using heparinized 2-mL gas syringes (PICO50, Radiometer A/S, Copenhagen, Denmark). Samples were immediately placed on crushed ice. Arterial, portal, hepatic, and ruminal blood samples were drawn simultaneously using 20-mL disposable syringes, and the blood was immediately transferred to heparin vacuettes (\#455051, Greiner BioOne GmbH, Kremsmuenster, Austria). Small-volume blood samples after $\mathrm{D}_{2} \mathrm{O}$ dosing were obtained using $10-\mathrm{mL}$, singleuse syringes and handled as ordinary samples. For all samples, vacuettes were placed on ice immediately after sampling, and plasma was harvested by centrifugation at $3,000 \times g$ for $20 \mathrm{~min}$ at $4^{\circ} \mathrm{C}$. Plasma was stored at $-20^{\circ} \mathrm{C}$ until analysis.

Ruminal fluid from the ventral ruminal sac was sampled every hour plus 6 and 12 min after intraruminal $\mathrm{D}_{2} \mathrm{O}$ dosing using an extended suction strainer (\#RT, Bar Diamond, Parma, ID).

Milk yield was recorded at each milking and milk samples stored on sampling days using continuous flow sampling (TruTest HI, Tru-Test Scandinavia, Præstø, 
Denmark). Urine was sampled every hour by stimulating the cow to urinate by hand sweeping the supramammary region.

\section{Analytical Procedures}

Hematocrit was determined immediately in arterial samples (6 samples/d) by centrifugation in capillary tubes at $13,000 \times g$ for 6 min at ambient temperature. Ruminal and urinary $\mathrm{pH}$ were measured using a combination electrode (PHC2002-8, Hach Lange APS, Brønshøj, Denmark) and a $\mathrm{pH}$ meter calibrated at $\mathrm{pH}$ 4.005 and 7.000 (PHM 240, Hach Lange APS). Blood $\mathrm{pH}$, blood gases, and oximetry variables were measured using an ABL700 Blood Gas Analyzer (Radiometer $\mathrm{A} / \mathrm{S})$.

Plasma samples were analyzed for glucose and Llactate using D-glucose oxidase and L-lactate oxidase, respectively (YSI 7100, YSI Inc., Yellow Springs, OH). Plasma and urine pAH were deacetylated before analysis by the method described by Harvey and Brothers (1962) using a continuous flow analyzer (Autoanalyzer 3, method US-216-72 Rev.1; Seal Analytical Ltd., Burgess Hill, UK). Before deacetylation of pAH, plasma was deproteinized by combining with an equal volume of $20 \%$ trichloroacetic acid (wt/vol) and the supernatant incubated at $100^{\circ} \mathrm{C}$ for $1 \mathrm{~h}$. Plasma and urine concentrations of urea were determined by the method described by Marsh et al. (1965) using a continuous flow analyzer (Autoanalyzer 3, method G-373-07 Rev. 1). Urea was determined in samples that had not been heat treated or deproteinized. Plasma concentrations of ammonia were determined using an enzymatic assay (AM 1015, Randox Laboratories Ltd., Crumlin, UK) adapted for use on a Cobas Mira autoanalyzer (Triolab A/S, Brøndby, Denmark).

Milk samples were analyzed for fat, protein, and lactose (monohydrate) by infrared spectrometry using a MilkoScan 4000 (Eurofins Steins A/S, Holstebro, Denmark). Milk urea content was determined by the monoxime diacetyl method (see above) following deproteinization by combining raw milk samples with an equal volume of $24 \%$ trichloroacetic acid.

Frozen pooled samples of silages were analyzed by near infrared spectroscopy at a commercial feed testing laboratory (Eurofins Steins Laboratorium A/S). Pooled samples of TMR were analyzed as described previously (Kristensen et al., 2007).

Plasma and rumen fluid samples were analyzed for $\mathrm{D}_{2} \mathrm{O}$ by high-temperature conversion elemental analysis-isotope ratio mass spectrometry (Finnigan Delta V Plus, Thermo Scientific, Bremen, Germany). Matrix water was separated by ultrafiltration (Pall Nanosep 10K Omega, VWR Bie \& Berntsen A/S, Herlev, Denmark) before injection.

\section{Calculations and Statistical Procedures}

Intraruminal dosing with $\mathrm{D}_{2} \mathrm{O}$ resulted in extremely variable abundances of deuterium in ruminal water, and we were unable to calculate the rumen epithelial blood flow. One cow did not have a functional portal catheter; thus, portal - arterial differences and net portal fluxes are reported for only 8 cows.

The ammonia concentration in whole blood was set equal to the plasma concentration, whereas the wholeblood concentration of urea was obtained by correcting for the urea dilution space in erythrocytes $[80 \%$ of erythrocyte volume; B. A. Røjen (Faculty of Agricultural Sciences, Aarhus University, Tjele, Denmark) and N. B. Kristensen; unpublished data].

Portal and ruminal vein extractions for urea were calculated as follows: $100 \times$ (arterial urea concentration - venous urea concentration)/arterial urea concentration.

The portal blood plasma flow was calculated as infusion rate of $\mathrm{pAH} /$ (portal plasma $\mathrm{pAH}$ concentration arterial plasma pAH concentration). The hepatic blood plasma flow was calculated as infusion rate of $\mathrm{pAH} /$ (hepatic plasma pAH concentration - arterial plasma pAH concentration). The net portal flux was calculated as portal blood or plasma flow $\times$ (portal concentration - arterial concentration), using whole blood or plasma values as indicated. The net hepatic flux was calculated as hepatic blood or plasma flow $\times$ hepatic concentration $-[$ (portal blood or plasma flow $\times$ portal concentration $)+$ (hepatic arterial blood or plasma flow $x$ arterial concentration)], where the hepatic arterial blood or plasma flow was calculated as hepatic blood or plasma flow - portal blood or plasma flow. The net splanchnic flux was calculated as hepatic blood or plasma flow $\times$ (hepatic concentration - arterial concentration). Whole blood flows were calculated as plasma flow/[1 - (hematocrit/100)]. Positive net fluxes indicate production or release, whereas negative net fluxes indicate uptake or transfer of the substance. The $\mathrm{D}_{2} \mathrm{O}$ dilution space was calculated from the measured $\mathrm{D}_{2} \mathrm{O}$ infusion excess/(plasma $\mathrm{D}_{2} \mathrm{O}$ abundance at last blood sampling - plasma $\mathrm{D}_{2} \mathrm{O}$ abundance at first blood sampling). The equilibration time for $\mathrm{D}_{2} \mathrm{O}$ was more than $4 \mathrm{~h}$. The urea dilution space was calculated from the urea priming dose +12 min of continuous urea infusion/(arterial urea concentration at the first sampling 15 min after urea infusion initiated - the arterial urea concentration in the sample preceding urea infusion).

Urinary excretion rate was calculated as the urinary concentration $\times$ diuresis at hourly intervals. Diuresis was calculated as infusion rate of pAH/urinary pAH concentration. The renal plasma flow was calculated as infusion rate of $\mathrm{pAH} /$ arterial concentration of $\mathrm{pAH}$ 
also decreased $(P<0.01)$. The protein and urea concentration in milk decreased $(P<0.01)$ with the low-N diet. Milk fat and lactose concentrations were not affected by treatment $(P \geq 0.54)$. The calculated energy balance was negative for both treatments in line with the relatively early stage of lactation and most negative $(P=0.05)$ for low-N. The calculated apparent $\mathrm{N}$ utilization for milk production was greater $(P<0.01)$ for low-N compared with high-N.

\section{Ruminal Variables}

The ammonia concentration in ventral ruminal fluid was greater before infusion $(P<0.01)$ for high-N compared with low-N, and the observed tendency for a dietary treatment $\times$ urea infusion interaction $(P=0.06)$ reflected an increased concentration with urea infusion with low-N and decreasing concentration with urea infusion for high-N (Table 3). It has to be considered that urea infusion was confounded with time after feeding, and the expected differences in ruminal ammonia patterns among treatments probably influenced the apparent interaction between urea infusion and treatment on ruminal ammonia concentrations.

\section{Arterial Variables}

Arterial blood $\mathrm{pH}$ was lower $(P<0.01)$ before infusion for low-N compared with high-N animals, and no difference could be detected with infusion (Table 3). Arterial hematocrit and arterial concentrations of oxygen and carbon dioxide were not affected $(P=0.19$ to $P>0.99$ ) by treatment or infusion.

The arterial blood concentration of urea increased similarly $(1.91 \pm 0.13 \mathrm{mmol} / \mathrm{L}$; interaction $P=0.47)$ to initiation of urea infusion with both dietary treatments. Relatively constant arterial concentrations were observed before and after initiation of the primed intravenous infusion (Figure 1). The arterial ammonia concentration was greater $(P=0.01)$ for high-N before urea infusion and tended $(P=0.08)$ to be greater for high-N also during urea infusion.

The arterial plasma concentration of $\mathrm{pAH}$ was greater $(P<0.01)$ for low-N both before and during urea infusion, indicating a treatment effect on renal excretion of pAH because pAH infusion rates were similar between treatments (low-N, 32.7 and high-N, $31.3 \pm 0.7$ $\mathrm{mmol} / \mathrm{h})$. The arterial plasma concentration of glucose tended to be lower $(P=0.07)$ before infusion for low$\mathrm{N}$ compared with high-N; however, no difference $(P=$ $0.27)$ in arterial glucose concentration between dietary treatments was detected during urea infusion. Plasma L-lactate concentration did not differ $(P=0.37$ to $P=$ 0.51 ) between treatments.

\section{Portal - Arterial and Ruminal Vein - Arterial Concentration Differences}

The portal - arterial (PA) difference for urea was greater $(P=0.03)$ for high-N compared with low-N before infusion and did not differ between treatments $(P=0.61)$ during urea infusion (Table 4). The ruminal vein - arterial (RA) difference for urea did not differ before infusion $(P=0.82)$ and was greater $(P<0.01)$ for low-N compared with high-N after initiation of urea infusion. Accordingly, the interaction between urea infusion and dietary treatment approached significance $(P=0.06)$ for the RA difference of urea.

The observed PA and RA differences for urea were obtained with markedly different arterial urea concentrations between treatments and therefore reflect relatively large differences in extraction of urea across the tissue beds. No interactions $(P=0.33$ to $P=0.35)$ between treatment and urea infusion were observed for portal or ruminal urea extraction from arterial blood. The urea extraction from arterial blood remained very different $(P<0.01)$ between treatments before and after initiation of urea infusion, and extractions remained constant before and during urea infusion within dietary treatment.

The PA difference for ammonia was greater $(P<$ 0.01 ) for high- $\mathrm{N}$ compared with low- $\mathrm{N}$ both before and during urea infusion, but the induced increase by infusion tended $(P=0.09)$ to be greater in the low-N group. This effect was more pronounced for the RA differences for ammonia where the treatment difference was greater before infusion compared with the PA difference. However, a strong interaction $(P<0.01)$ was observed between dietary treatment and urea infusion, reflecting a doubling of the RA difference for ammonia during urea infusion for low-N compared with a minute increase during urea infusion for high-N.

\section{Blood Flows and Net Fluxes}

The portal, hepatic, and hepatic arterial blood plasma flows were not affected ( $P=0.40$ to $P=0.95)$ by dietary treatment before or during urea infusion. The hepatic plasma flow decreased $(P=0.01)$ and the portal plasma flow tended $(P=0.09)$ to decrease with infusion (Table 5). Again, it has to be recognized that these effects of infusion are overlying the postprandial patterns for these variables.

The net portal uptake (negative net portal flux) of urea was lower $(P=0.02)$ for low-N compared with high-N before infusion, but the net portal urea uptake was not different $(P=0.61)$ between dietary treatments during urea infusion, and the difference in response to infusion between treatments was reflected 
Table 3. Ruminal and arterial variables

Treatment $(\mathrm{Trt})^{1}$

\begin{tabular}{|c|c|c|c|c|c|c|c|c|c|}
\hline Item & $\begin{array}{l}\text { Before urea } \\
\text { infusion }^{2}\end{array}$ & $\begin{array}{l}\text { With urea } \\
\text { infusion }^{3}\end{array}$ & $\begin{array}{l}\text { Before urea } \\
\text { infusion }\end{array}$ & $\begin{array}{l}\text { With urea } \\
\text { infusion }\end{array}$ & SEM & Infusion $(\mathrm{I})^{4}$ & $\begin{array}{l}\text { Low vs. high } \\
\text { before }^{5}\end{array}$ & $\begin{array}{c}\text { Low vs. high } \\
\text { with }^{6}\end{array}$ & $\operatorname{Trt} \times I^{7}$ \\
\hline \multicolumn{10}{|l|}{ Ruminal variables } \\
\hline Ammonia, mmol/L & 1.56 & 2.68 & 4.31 & 3.10 & 0.60 & 0.93 & $<0.01$ & 0.62 & 0.06 \\
\hline Ventral ruminal $\mathrm{pH}$ & 6.66 & 6.61 & 6.42 & 6.59 & 0.12 & 0.17 & 0.19 & 0.92 & 0.02 \\
\hline \multicolumn{10}{|l|}{ Arterial whole blood } \\
\hline $\mathrm{pH}$ & 7.42 & 7.42 & 7.44 & 7.44 & 0.01 & 0.84 & $<0.01$ & 0.11 & 0.32 \\
\hline Hematocrit, proportion & 0.25 & 0.25 & 0.25 & 0.25 & 0.01 & $>0.99$ & $>0.99$ & $>0.99$ & $>0.99$ \\
\hline Oxygen, mmol/L & 5.22 & 5.20 & 5.15 & 5.13 & 0.13 & 0.46 & 0.32 & 0.36 & 0.89 \\
\hline Carbon dioxide, $\mathrm{mmol} / \mathrm{L}$ & 26.79 & 26.71 & 27.35 & 26.63 & 0.56 & 0.19 & 0.19 & 0.85 & 0.29 \\
\hline Urea, $\mathrm{mmol} / \mathrm{L}$ & 1.37 & 3.38 & 4.09 & 5.91 & 0.18 & $<0.01$ & $<0.01$ & $<0.01$ & 0.47 \\
\hline Ammonia, mmol/L & 0.105 & 0.120 & 0.117 & 0.128 & 0.005 & $<0.01$ & 0.01 & 0.08 & 0.51 \\
\hline \multicolumn{10}{|l|}{ Arterial blood plasma } \\
\hline$p$-aminohippurate, $\mathrm{mmol} / \mathrm{L}$ & 0.097 & 0.102 & 0.080 & 0.083 & 0.004 & 0.04 & $<0.01$ & $<0.01$ & 0.43 \\
\hline Glucose, $\mathrm{mmol} / \mathrm{L}$ & 3.40 & 3.55 & 3.61 & 3.67 & 0.08 & 0.06 & 0.07 & 0.27 & 0.44 \\
\hline L-lactate, $\mathrm{mmol} / \mathrm{L}$ & 0.26 & 0.27 & 0.31 & 0.30 & 0.04 & 0.88 & 0.37 & 0.51 & 0.82 \\
\hline
\end{tabular}

${ }^{1}$ Treatments were feeding a TMR with low CP content (low N; $12.9 \% \mathrm{CP}$ ) and high CP content (high N; $17.1 \% \mathrm{CP}$ ) in a crossover design with sampling after $14 \mathrm{~d}$ of adaptation.

${ }^{2}$ Mean of 5 samples obtained during a 2.5-h period before initiation of intravenous urea infusion.

${ }^{3}$ Mean of samples obtained during a 2.5-h period with primed continuous intravenous infusion of urea $(0.493 \pm 0.012 \mathrm{mmol} / \mathrm{kg}$ of BW per h)

${ }^{4} F$-test for overall effect of urea infusion, which is confounded with time after feeding.

${ }^{5}$ Contrast for before infusion low $\mathrm{N}$ versus before infusion high $\mathrm{N}$.

${ }^{6}$ Contrast for with infusion low $\mathrm{N}$ versus with infusion high $\mathrm{N}$.

${ }^{7}$ Interaction between dietary treatment (Trt) and urea infusion. 


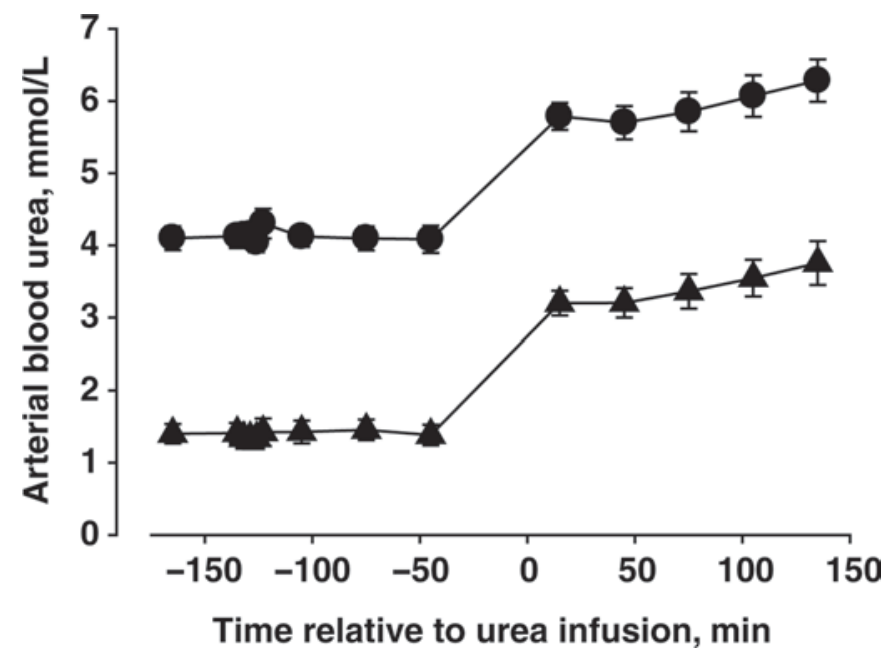

Figure 1. Arterial blood concentration of urea $(\mathrm{mmol} / \mathrm{L})$ in lactating Holstein cows fed a low-N $(\boldsymbol{\Lambda}, 12.9 \% \mathrm{CP})$ and a high-N $(\bullet, 17.1 \%$ $\mathrm{CP})$ ration in a crossover design before and after initiation (time = 0 ) of a primed continuous intravenous infusion of urea $(0.493 \pm 0.012$ $\mathrm{mmol} / \mathrm{kg}$ of BW per h). Data points represent the means of 9 cows \pm SEM.

in the tendency $(P=0.06)$ to an interaction between dietary treatment and infusion. The net portal release of ammonia was lower for low-N before and during urea infusion and tended $(P=0.09)$ to increase more with urea infusion when cows were fed low-N compared with high-N. Net portal fluxes of oxygen and carbon dioxide were not affected $(P=0.41$ to $P=0.90)$ by dietary treatment or urea infusion.

The net portal glucose release (positive net portal flux) was not affected $(P=0.18$ to $P=0.58)$ by treatment, but increased $(P=0.05)$ with urea infusion. The net portal L-lactate release was lower $(P=0.08$ to $P<$ 0.01 ) for low-N compared with high-N.

The net hepatic urea release increased $(P=0.04)$ with urea infusion and was greater $(P<0.01)$ in the high-N group both before and during urea infusion. The net hepatic ammonia uptake increased with infusion and remained lower $(P<0.01)$ for low-N both before and during urea infusion. The hepatic ammonia uptake supplied, on a net basis, $82 \pm 6 \%$ of the net hepatic flux of urea- $\mathrm{N}$ for low- $\mathrm{N}$ before infusion as well as high-N both before and during infusion; however, the combination of low- $\mathrm{N}$ and urea infusion resulted in ammonia uptake accounting for the entire net hepatic flux of urea-N (interaction $P=0.05$; data not shown).

The net hepatic oxygen uptake was greater $(P=0.05)$ with infusion for high-N compared with low-N, but no interaction $(P=0.70)$ between dietary treatment and infusion could be detected, reflecting a similar numerical treatment difference also before infusion. The net hepatic carbon dioxide release was not affected $(P=$ 0.65 to $P=0.98$ ) by treatment or infusion.

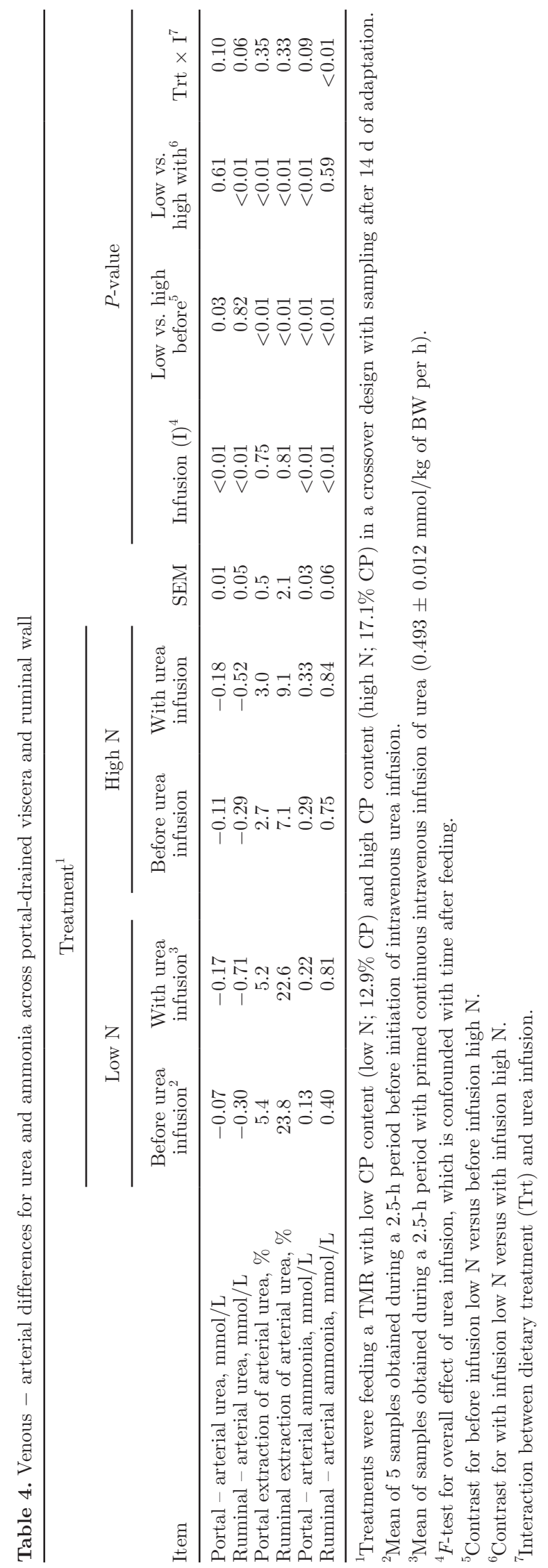

Journal of Dairy Science Vol. 93 No. 6, 2010 
Table 5. Blood plasma flows, net portal, net hepatic, and net splanchnic fluxes

\begin{tabular}{|c|c|c|c|c|c|c|c|c|c|}
\hline \multirow[b]{2}{*}{ Item } & \multicolumn{4}{|c|}{ Treatment $^{1}$} & \multirow[b]{2}{*}{ SEM } & \multicolumn{4}{|c|}{$P$-value } \\
\hline & $\begin{array}{l}\text { Before urea } \\
\text { infusion }^{2}\end{array}$ & $\begin{array}{l}\text { With urea } \\
\text { infusion }^{3}\end{array}$ & $\begin{array}{l}\text { Before urea } \\
\text { infusion }\end{array}$ & $\begin{array}{l}\text { With urea } \\
\text { infusion }\end{array}$ & & $\begin{array}{l}\text { Infusion } \\
(\mathrm{I})^{4}\end{array}$ & $\begin{array}{l}\text { Low vs. high } \\
\text { before }^{5}\end{array}$ & $\begin{array}{l}\text { Low vs. } \\
\text { high with }\end{array}$ & $\operatorname{Trt} \times \mathrm{I}^{7}$ \\
\hline \multicolumn{10}{|l|}{ Blood plasma flows } \\
\hline Portal, L/h & 1,444 & 1,378 & 1,489 & 1,403 & 86 & 0.09 & 0.47 & 0.71 & 0.80 \\
\hline \multicolumn{10}{|l|}{ Net portal whole-blood flux } \\
\hline Urea, $\mathrm{mmol} / \mathrm{h}$ & -142 & -313 & -211 & -326 & 34 & $<0.01$ & 0.02 & 0.61 & 0.06 \\
\hline Ammonium, mmol/h & 263 & 442 & 629 & 646 & 55 & 0.04 & $<0.01$ & $<0.01$ & 0.09 \\
\hline Oxygen, mmol/h & $-2,402$ & $-2,483$ & $-2,511$ & $-2,466$ & 143 & 0.82 & 0.41 & 0.86 & 0.47 \\
\hline Carbon dioxide, $\mathrm{mmol} / \mathrm{h}$ & 3,209 & 3,169 & 3,156 & 2,810 & 285 & 0.51 & 0.90 & 0.37 & 0.58 \\
\hline \multicolumn{10}{|l|}{ Net portal plasma flux } \\
\hline Glucose, $\mathrm{mmol} / \mathrm{h}$ & -2 & 24 & 17 & 32 & 17 & 0.05 & 0.18 & 0.56 & 0.58 \\
\hline Carbon dioxide, $\mathrm{mmol} / \mathrm{h}$ & 1,356 & 1,360 & 1,456 & 1,429 & 245 & 0.98 & 0.65 & 0.85 & 0.80 \\
\hline \multicolumn{10}{|l|}{ Net hepatic plasma flux } \\
\hline Glucose, $\mathrm{mmol} / \mathrm{h}$ & 637 & 566 & 768 & 711 & 33 & 0.01 & 0.02 & 0.01 & 0.78 \\
\hline L-lactate, $\mathrm{mmol} / \mathrm{h}$ & -194 & -188 & -207 & -186 & 23 & 0.28 & 0.45 & 0.90 & 0.53 \\
\hline \multicolumn{10}{|c|}{ Net splanchnic whole-blood flux } \\
\hline Urea, $\mathrm{mmol} / \mathrm{h}$ & 22 & -95 & 168 & 76 & 21 & $<0.01$ & $<0.01$ & $<0.01$ & 0.53 \\
\hline Ammonium, mmol/h & 4.0 & 4.8 & -0.6 & $<0.1$ & 3.7 & 0.83 & 0.31 & 0.31 & $>0.99$ \\
\hline Oxygen, $\mathrm{mmol} / \mathrm{h}$ & $-4,819$ & $-4,790$ & $-5,316$ & $-5,144$ & 307 & 0.53 & 0.02 & 0.10 & 0.52 \\
\hline Carbon dioxide, $\mathrm{mmol} / \mathrm{h}$ & 4,422 & 4,518 & 4,304 & 4,250 & 257 & 0.85 & 0.68 & 0.29 & 0.64 \\
\hline \multicolumn{10}{|l|}{ Net splanchnic plasma flux } \\
\hline Glucose, $\mathrm{mmol} / \mathrm{h}$ & 642 & 599 & 785 & 740 & 36 & 0.09 & $<0.01$ & $<0.01$ & 0.97 \\
\hline L-lactate, $\mathrm{mmol} / \mathrm{h}$ & -39 & -33 & -13 & 23 & 18 & 0.11 & 0.21 & 0.01 & 0.26 \\
\hline
\end{tabular}

${ }^{1}$ Treatments were feeding a TMR with low CP content (low N; $12.9 \% \mathrm{CP}$ ) and high CP content (high N; 17.1\% CP) in a crossover design with sampling after $14 \mathrm{~d}$ of adaptation.

${ }^{2}$ Mean of 5 samples obtained during a 2.5-h period before initiation of intravenous urea infusion.

${ }^{3}$ Mean of samples obtained during a 2.5 -h period with primed continuous intravenous infusion of urea $(0.493 \pm 0.012 \mathrm{mmol} / \mathrm{kg}$ of BW per h).

${ }^{4} F$-test for overall effect of urea infusion, which is confounded with time after feeding.

${ }^{5}$ Contrast for before infusion low $\mathrm{N}$ versus before infusion high $\mathrm{N}$.

${ }^{6}$ Contrast for with infusion low $\mathrm{N}$ versus with infusion high $\mathrm{N}$.

${ }^{7}$ Interaction between dietary treatment (Trt) and urea infusion.

The net hepatic flux of glucose was less $(P=0.02$ to $P=0.01)$ for low-N compared with high-N before and during urea infusion, and the net hepatic flux of glucose decreased $(P=0.01)$ during infusion. The net hepatic flux of glucose per kilogram of DMI was not affected by treatment $(34 \pm 1 \mathrm{mmol} / \mathrm{h}$ per $\mathrm{kg}$ of DMI; $P=0.15)$. The net hepatic flux of L-lactate was not affected by treatment or infusion $(P=0.45$ to $P=0.90)$.

The net splanchnic flux of urea differed $(P<0.01)$ with treatment before and during infusion, and a negative net splanchnic flux of urea was observed during infusion for low-N; that is, larger uptake of urea across gut epithelia than produced in the liver driven by intravenous urea infusion. The net splanchnic flux of ammonia was not affected by treatment or infusion $(P$ $=0.31$ to $P=0.83)$ and was not different $(P=0.45)$ from zero. The net splanchnic uptake of oxygen was lower $(P=0.10$ to $P=0.02)$ for the low-N group. The net splanchnic flux of carbon dioxide was not affected ( $P=0.29$ to $P=0.85)$ by treatment or infusion.

The net splanchnic flux of glucose was less $(P<0.01)$ for low-N compared with high-N and tended to decrease $(P=0.09)$ with infusion. The net splanchnic flux of $\mathrm{L}^{-}$ lactate was greater $(P=0.01)$ with infusion when cows were fed high-N compared with the low-N diet.

\section{Renal Variables}

Urinary $\mathrm{pH}$ was less $(P<0.01)$ for low-N compared with high-N before infusion, but the difference could not be detected with infusion. Diuresis was not affected ( $P=0.11$ to $P=0.98)$ by treatment or urea infusion. 
The renal plasma flow was lower $(P<0.01)$ for low-N compared with high-N before and during urea infusion (Table 6). The urinary concentration and excretion rate of urea was less $(P<0.01)$ for low-N compared with high-N before and during urea infusion, but increased $(P<0.01)$ during urea infusion. No interactions $(P=$ 0.26 to $P=0.44$ ) between treatment and infusion were observed for urinary urea concentrations and excretion rates. The renal clearance of blood urea was less $(P<$ $0.01)$ and the PDV clearance of blood urea greater $(P$ $<0.01$ ) for low-N compared with high-N before and during urea infusion. The renal clearance of blood urea decreased slightly $(P<0.01)$ during urea infusion. The estimated salivary flux of urea was not affected $(P=$ 0.27 to $P=0.31$ ) by dietary treatment, but increased $(P<0.01)$ with urea infusion. The salivary urea flux was not different $(P=0.81)$ from zero before urea infusion.

\section{DISCUSSION}

No adverse reactions to intravenous urea infusion were observed in the present experiment and no sign of erythrocyte lysis was apparent in blood plasma.

\section{Urea Transport}

The fundamental question to be addressed by the present study was related to the properties of the epithelial transport mechanism for urea. Two overall hypotheses can explain the generally observed relationship between epithelial urea supply and transport in cattle: A) mass action-driven transport combined with downregulation of epithelial urea permeability with increasing $\mathrm{N}$ status, and $\mathrm{B}$ ) fixed transport capacity for urea across the epithelia independent of blood urea supply to the epithelium. Compiling data from several studies on dairy cows showed a curvilinear relationship between plasma urea concentration and the extraction of urea across the PDV with a decreasing extraction with increasing urea concentration (Røjen et al., 2008; Calsamiglia et al., 2010). The overall transport rate of urea across the epithelia in these previous experiments has been remarkably unaffected by plasma urea concentration and $\mathrm{N}$ status of the cows; however, because all dietary intervention studies have allowed time for adaptation of epithelial urea transport, we cannot tell if the system behaves according to hypothesis A or B.

The simplest possible explanation of the observed transport rates for urea would be a transport system operating with a fixed transport rate independent of urea supply; that is, that the $\mathrm{N}$ status did not affect epithelial transport but only epithelial supply of urea (hypothesis B). This conclusion would, however, con-

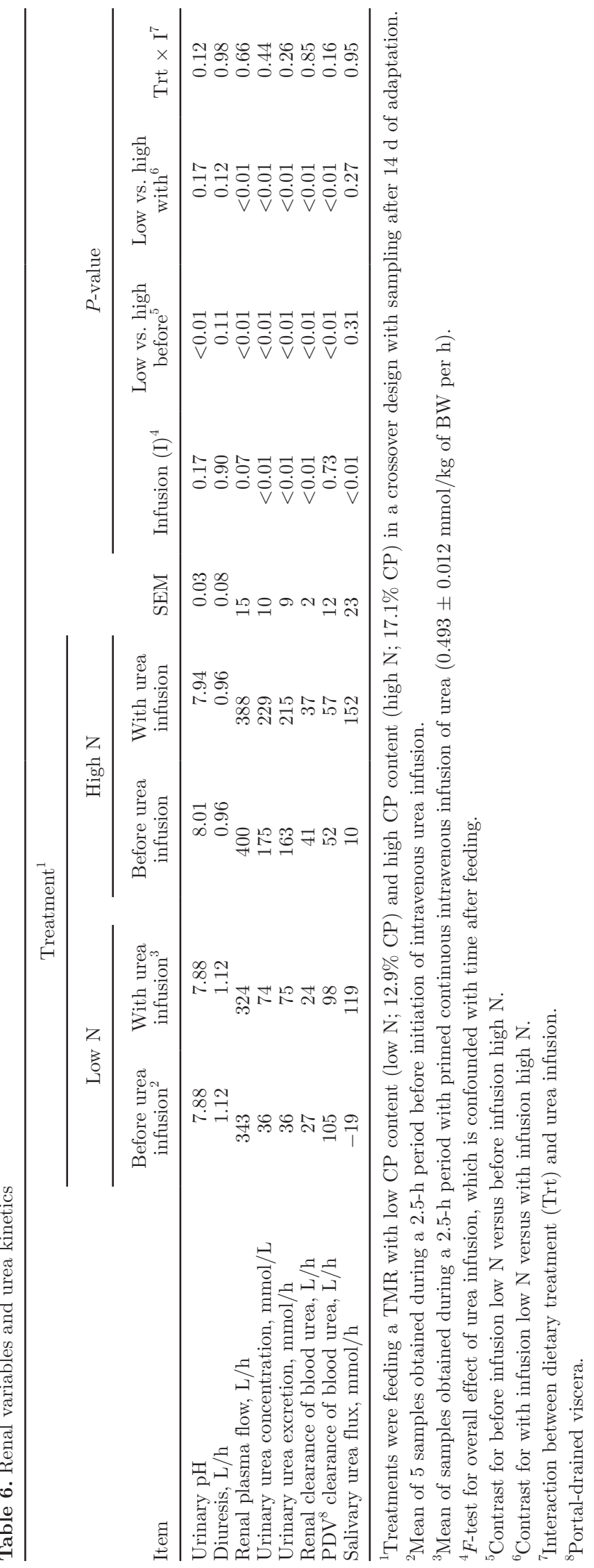

Journal of Dairy Science Vol. 93 No. 6, 2010 
tradict observations on urea transport in sheep and goats indicating linear relationships between blood plasma concentrations of urea and the transfer of urea across the rumen wall (Houpt, 1970; Harmeyer and Martens, 1980; Sunny et al., 2007). The present study demonstrates that in the lactating cow, urea transport across gut epithelia is directly proportional to the blood concentration of urea; that is, the extraction upon passage of the epithelial bed is constant, and transport is regulated by mass action. However, urea transport across the epithelia was clearly affected by the nutritional state of the cow (Table 4), implying that epithelial urea permeability is being downregulated in cattle along with increasing $\mathrm{N}$ status. The $\mathrm{N}$ status is used here as a broad term related to both ruminal ammonia and blood urea concentrations as these are correlated, and the former especially has been assumed critical for adaptation of urea permeability of gut epithelia (Kennedy and Milligan, 1980).

Our inability to obtain proper mixing of $\mathrm{D}_{2} \mathrm{O}$ in the rumen water pool made it impossible to directly quantify ruminal versus PDV net fluxes of urea in the present study. However, data demonstrate a remarkable upregulation of urea extraction with the low-N diet especially across the rumen wall. The PDV extraction of urea increased approximately 1.8-fold for low-N compared with high-N, but the ruminal extraction of urea increased approximately 2.9-fold, indicating differential regulation of urea transport among different gut tissues. Upregulation of urea transfer to the rumen relative to distal segments of the gastrointestinal tract is in line with observations on sheep (Norton et al., 1982; Siddons et al., 1985). It could be speculated that the differential regulation was caused by a specific upregulation of forestomach epithelial urea transport with a relative constant urea transport by post-ruminal tissues.

Urea transporter B is expressed in ruminal epithelium (Stewart et al., 2005) and the expression has been shown to correlate with energy intake in cattle (Simmons et al., 2009). However, expression of urea transporter B does not apparently correlate with epithelial permeability for urea (Marini and Van Amburgh, 2003; Marini et al., 2004); the molecular basis for regulating urea permeability of the ruminal epithelium remains to be determined and might involve aquaporins (Litman et al., 2009) or bacterial permease toxins yet to be identified (Stewart and Smith, 2005). The present study shows that urea permeability of ruminal epithelium is an adaptable property of the epithelium that is not subjected to immediate feedback from increasing ammonia and urea concentrations.

One of the fundamental problems related to increasing $\mathrm{N}$ efficiency of cattle by means of utilizing their ability to recycle urea to the gut seems to be that the ruminal epithelial urea permeability is starting to decline when $\mathrm{N}$ status is still insufficient to sustain maximal rumen microbial growth.

\section{Ammonia}

The observed ruminal ammonia concentration with low-N was low compared with classic estimates of the minimal ruminal ammonia level needed to maximize microbial activity (3.6 mmol/L; Satter and Slyter, 1974). In addition, the ruminal ammonia level with high-N was relatively low compared with a range of different estimates of the ruminal ammonia levels needed to maximize microbial activity (for discussion, see Reynal and Broderick, 2005).

Urea transferred across the ruminal epithelium is subjected to immediate hydrolysis by ureases expressed by epithelia-associated bacteria (Wallace et al., 1979) and accordingly, the RA concentration difference for ammonia responded immediately to the increased ruminal urea uptake with the low-N treatment (first sampling $15 \mathrm{~min}$ after initiation of urea infusion). At the level of the ruminal vein, $50 \%$ of the increased urea$\mathrm{N}$ uptake with infusion returned as increased ammonia release to the blood with low- $\mathrm{N}$, whereas this value was only $20 \%$ for high-N. This difference in ammonia return between treatments is opposite to the expected need for ammonia in the rumen; however, the effect could be influenced by a greater dietary induced postprandial peak in ammonia concentration with high-N. Thus, the difference in infusion-induced ammonia return has to be interpreted with caution although the relatively small fraction of urea- $\mathrm{N}$ retained by the rumen with low- $\mathrm{N}$ is in good agreement with the generally observed inefficiency by which recycled urea- $\mathrm{N}$ is incorporated into rumen microbial biomass (Sunny et al., 2007).

It could be speculated that microbial colonization of the epithelium leads to build-up of ammonia in the epithelium and that this epithelial pool of ammonia from hydrolyzed urea equilibrates poorly with the rumen ammonia pool explaining the relatively low correlation $(\mathrm{r}=0.55, P<0.01)$ between ventral ruminal ammonia concentration and RA difference for ammonia. These difficulties in predicting ammonia absorption from rumen ammonia concentrations have been previously recognized (Rémond et al., 1996). The correlation between ruminal ammonia concentration and the RA difference for ammonia was not improved by correction for free ammonia versus ammonium in the ventral ruminal fluid $(\mathrm{r}=0.53, P<0.01, \mathrm{p} K \mathrm{a}$ for ammonium at $37^{\circ} \mathrm{C}$ set to 8.9 ) although it is commonly assumed that ammonia has greater ruminal permeability than ammonium (Rémond et al., 1996). Relating the RA 
difference for ammonia to a function of ruminal ammonia concentration (total ammonia + ammonium) and the RA difference for urea markedly improved the model $(\mathrm{r}=0.85, P<0.01$; ruminal vein - arterial difference for ammonia in $\mathrm{mmol} / \mathrm{L}=0.096 \pm 0.009 \times$ ruminal ammonia concentration in $\mathrm{mmol} / \mathrm{L}+0.884 \pm$ $0.063 \times$ arterial - ruminal vein urea concentration in $\mathrm{mmol} / \mathrm{L}$ ). Our data, as well as the presented equation, indicate that a major part of ammonia released to the ruminal vein in dairy cattle does not originate from the rumen fluid but is absorbed from a urea hydrolysis pool within the ruminal epithelium not in equilibrium with the ventral ruminal ammonia pool. It seems that rumen epithelial colonization of urealytic bacteria is a fundamental obstacle to the use of recycled urea- $\mathrm{N}$ to improve $\mathrm{N}$ efficiency of dairy cattle and probably other ruminants. These observations might also add to the speculation that the transport proteins expressed in the epithelium are microbial "toxins" acting as epithelial urea transporters and primarily benefit the epithelial population of microbes (Stewart and Smith, 2005). If this is true, it might also contribute to the long-lasting puzzle of the relationship between rumen urease activity and epithelial urea permeability and it could be speculated that the bacteria expressing urease when ammonia availability is low also regulate their expression of "urea-permease-toxins" according to the availability of ammonia.

\section{Urea Kinetics}

The observed changes in renal urea kinetics point toward a differential regulation of urea transport in the PDV and kidneys as well as within the different tissues of the PDV. The observed changes in blood urea clearance by the kidneys in the present study (0.048 to 0.073 $\mathrm{L} / \mathrm{h}$ per $\mathrm{kg}$ of $\mathrm{BW}$ ) were in line with the range observed in Holstein heifers fed variable $\mathrm{N}$ intakes $(0.044$ to 0.078 $\mathrm{L} / \mathrm{h}$ per $\mathrm{kg}$ of BW; Marini and Van Amburgh, 2003). The wider range for the heifers could reflect the more extreme diets fed to the heifers (9 to $21 \% \mathrm{CP}$ versus 13 to $17 \% \mathrm{CP}$ in the present study). In the study on Holstein heifers, plasma creatinine clearance was unaffected by $\mathrm{N}$ intake and the data therefore point toward increased renal reabsorption of filtered urea with low $\mathrm{N}$ diets in line with the demonstrated ability of other species to regulate expression of urea transporters in the renal collecting ducts (Cirio and Boivin, 1990; Sands, 1999). From the observations on Holstein heifers, it might also be inferred that the decreased renal plasma flow with low- $\mathrm{N}$ deduced from the increased plasma concentration of $\mathrm{pAH}$ in the present study does not reflect a reduced glomerular filtration rate.
Estimates on salivary urea fluxes in cattle are relatively scarce (Huntington, 1989; Taniguchi et al., 1995; $\mathrm{R} \varnothing \mathrm{jen}$ et al., 2008). However, these previous studies, in agreement with the observations from the present study, point toward a minor importance of the salivary urea flux in cattle fed moderate to low $\mathrm{N}$ levels. The strong correlation between urea concentrations in plasma and saliva (saliva urea $=0.65 \times$ plasma urea; Bailey and Balch, 1961) and the generally observed downregulation of PDV extraction of arterial urea at high plasma urea concentrations (Calsamiglia et al., 2010) explains why salivary urea fluxes primarily play a role in urea allocation with high plasma concentrations of urea (in line with the observations for the alfalfa treatment in Huntington, 1989).

\section{Metabolic Effects of Treatments}

The low- $\mathrm{N}$ diet acidified the cows as evaluated from lower $\mathrm{pH}$ in arterial blood and urine. This effect was not intended and was much stronger than expected from the treatment difference in DCAD $(12 \mathrm{mEq} / \mathrm{kg}$ of DM) and the general relationship between DCAD and blood pH (Erdman, 1993). However, the DCAD calculation does not account for the acidifying effect of monocalcium phosphate added to the low- $\mathrm{N}$ diet, which provides a substantial load of nonmetabolizable acid (maximum $38 \mathrm{mEq} / \mathrm{kg}$ of DM; estimated from $2.5 \mathrm{~g}$ of monocalcium phosphate $/ \mathrm{kg}$ of $\mathrm{DM}$; molecular weight $234.06 \mathrm{~g} / \mathrm{mol}$; and maximal contribution of 3.6 proton equivalents per mol at $\mathrm{pH} 7.4$ and $\mathrm{pKa}$ of monobasic phosphoric acid $=6.8$ ).

A tendency for a reduced arterial glucose concentration was observed with the low-N diet and might reflect an overall more negative energy balance with low-N. We could not detect a difference in ruminal propionate (data not shown), and hepatic glucose production was not affected when related to DMI. The overall reduction in milk yield was comparable to the response predicted by NRC (2001).

The energetic cost of hepatic detoxification of ammonia as evaluated by hepatic oxygen uptake has been a matter of debate (Reynolds, 2006). It has generally not been possible to detect changes in hepatic oxygen uptake in response to changes in hepatic ammonia uptake. In the present study, urea synthesis in the liver would account for 4 to $10 \%$ of hepatic oxygen uptake if urea synthesis consumes 4 ATP per urea (Meijer et al., 1990) and all ATP was generated by oxidative phosphorylation. The present study is in line with previous studies insofar as the increased hepatic ammonia uptake with infusion did not induce increased oxygen uptake by the liver. This might be because of changes in intrahepatic 
ATP use or a relatively large ATP production from substrate level phosphorylation.

\section{CONCLUSIONS}

Reduced dietary nitrogen content increased the extraction of arterial urea across the ruminal and PDV tissues along with an overall shift of urea extraction toward the rumen in lactating dairy cows. The dietinduced adaptation of arterial urea extraction across ruminal and PDV tissues was unaffected by short-term intravenous infusion of urea. Urea transport across gut epithelia in cattle is driven by mass action; however, the permeability of the epithelia adapts to dietary conditions and the total amount of urea transported across gut epithelia depends on both arterial urea concentration and permeability of the epithelia. Data are commensurable with a model for urea transport across gut epithelia based on regulated expression or activity of facilitative urea transporters.

\section{ACKNOWLEDGMENTS}

We gratefully acknowledge Birgit H. Løth, Anne Krustrup, Pia Jensen, Marie Engbæk, Thorkild N. Jakobsen, Ole H. Olsen, and the barn staff at Faculty of Agricultural Sciences, Aarhus University (Tjele, Denmark) for skilful technical assistance. Funding for the study was provided by the Commission of the European Communities (Brussels, Belgium; FP7, KBBE-2007-1), the Directorate for Food, Fisheries and Agri Business (Copenhagen, Denmark; \#3304-VMP-05-005), and Faculty of Agricultural Sciences, Aarhus University, Denmark.

\section{REFERENCES}

Bailey, C. B., and C. C. Balch. 1961. Saliva secretion and its relation to feeding in cattle 2. The composition and rate of secretion of mixed saliva in the cow during rest. Br. J. Nutr. 15:383-402.

Calsamiglia, S., A. Ferret, C. K. Reynolds, N. B. Kristensen, and A. M. Van Vuuren. 2010. Strategies for optimizing nitrogen use by ruminants. Animal In press.

Cirio, A., and R. Boivin. 1990. Urea recycling from the renal pelvis in sheep: A study with $\left[{ }^{14} \mathrm{C}\right]$ urea. Am. J. Physiol. Renal Physiol. 258:F1196-F1202

Erdman, R. 1993. Dietary buffers and anion-cation balance in relation to acid-base status, feed intake and milk composition in the dairy cow. Acta Vet. Scand. Suppl. 89:83-91.

Gonzalez-Ronquillo, M., J. Balcells, J. A. Guada, and F. Vicente. 2003 Purine derivative excretion in dairy cows: Endogenous excretion and the effect of exogenous nucleic acid supply. J. Dairy Sci. $86: 1282-1291$

Harmeyer, J., and H. Martens. 1980. Aspects of urea metabolism in ruminants with reference to the goat. J. Dairy Sci. 63:17071728.

Harvey, R. B., and A. J. Brothers. 1962. Renal extraction of paraaminohippurate and creatinine measured by continuous in vivo sampling of arterial and renal-vein blood. Ann. N. Y. Acad. Sci. $102: 46-54$
Houpt, T. R. 1970. Transfer of urea and ammonium to the rumen. Pages 119-131 in Physiology of Digestion and Metabolism in the Ruminant. A. T. Phillipson, ed. Oriel Press Ltd., Newcastle upon Tyne, UK.

Huntington, G. B. 1989. Hepatic urea synthesis and site and rate of urea removal from blood beef steers fed alfalfa hay or a high concentrate diet. Can. J. Anim. Sci. 69:215-223.

Kennedy, P. M., R. T. J. Clarke, and L. P. Milligan. 1981. Influences of dietary sucrose and urea on transfer of endogenous urea to the rumen of sheep and numbers of epithelial bacteria. Br. J. Nutr. 46:533-541.

Kennedy, P. M., and L. P. Milligan. 1980. The degradation and utilization of endogenous urea in the gastrointestinal tract of ruminants: A review. Can. J. Anim. Sci. 60:205-221.

Kristensen, N. B., A. Storm, B. M. L. Raun, B. A. Røjen, and D. L. Harmon. 2007. Metabolism of silage alcohols in lactating dairy cows. J. Dairy Sci. 90:1364-1377.

Larsen, M., and N. B. Kristensen. 2009. Effect of abomasal glucose infusion on splanchnic and whole-body glucose metabolism in periparturient dairy cows. J. Dairy Sci. 92:1071-1083.

Litman, T., R. Søgaard, and T. Zeuthen. 2009. Ammonia and urea permeability of mammalian aquaporins. Handb. Exp. Pharmacol. 190:327-358.

Marini, J. C., J. D. Klein, J. M. Sands, and M. E. Van Amburgh. 2004. Effect of nitrogen intake on nitrogen recycling and urea transporter abundance in lambs. J. Anim. Sci. 82:1157-1164.

Marini, J. C., and M. E. Van Amburgh. 2003. Nitrogen metabolism and recycling in Holstein heifers. J. Anim. Sci. 81:545-552.

Marsh, W. H., B. Fingerhut, and H. Miller. 1965. Automated and manual direct methods for the determination of blood urea. Clin. Chem. 11:624-627.

McAllan, A. B., and R. H. Smith. 1973. Degradation of nucleic acids in the rumen. Br. J. Nutr. 29:331-345.

Meijer, A. J., W. H. Lamers, and R. A. F. M. Chamuleau. 1990 Nitrogen metabolism and ornithine cycle function. Physiol. Rev. 70:701-748.

NRC. 2001. Nutrient Requirements of Dairy Cattle. 7th rev. ed. Natl. Acad. Sci., Washington, DC.

Norton, B. W., A. N. Janes, and D. G. Armstrong. 1982. The effects of intraruminal infusions of sodium bicarbonate, ammonium chloride and sodium butyrate on urea metabolism in sheep. Br. J. Nutr. $48: 265-274$

Rémond, D., F. Meschy, and R. Boivin. 1996. Metabolites, water and mineral exchanges across the rumen wall: mechanisms and regulation. Ann. Zootech. 45:97-119.

Reynal, S. M., and G. A. Broderick. 2005. Effect of dietary level of rumen-degraded protein on production and nitrogen metabolism in lactating dairy cows. J. Dairy Sci. 88:4045-4064.

Reynolds, C. K. 2006. Splanchnic amino acid metabolism in ruminants. Pages 225-248 in Ruminant Physiology: Digestion, Metabolism and Impact of Nutrition on Gene Expression, Immunology and Stress. K. Sejrsen, T. Hvelplund, and M. O. Nielsen, ed. Wageningen Academic Publishers, Wageningen, the Netherlands.

Reynolds, C. K., and N. B. Kristensen. 2008. Nitrogen recycling through the gut and the nitrogen economy of ruminants - An asynchronous symbiosis. J. Anim. Sci. 86(E. Suppl.):E293-E305.

Røjen, B. A., and N. B. Kristensen. 2009. Effect of nitrogen supply on inter-organ urea flux in dairy cows. Page 369 in Book of Abstracts of the 60th Annual Meeting of the European Association for Animal Production. Wageningen Academic Publishers, Wageningen, the Netherlands.

Røjen, B. A., P. Lund, and N. B. Kristensen. 2008. Urea and shortchain fatty acids metabolism in Holstein cows fed a low-nitrogen grass-based diet. Animal 2:500-513.

Sands, J. M. 1999. Regulation of renal urea transporters. J. Am. Soc. Nephrol. 10:635-646.

Satter, L. D., and L. L. Slyter. 1974. Effect of ammonia concentration on rumen microbial protein production in vitro. Br. J. Nutr. 32:199-208.

Siddons, R. C., J. V. Nolan, D. E. Beever, and J. C. MacRae. 1985. Nitrogen digestion and metabolism in sheep consuming diets 
containing contrasting forms and levels of N. Br. J. Nutr. 54:175187.

Simmons, N. L., A. S. Chaudhry, C. Graham, E. S. Scriven, A. Thislethwaite, C. P. Smith, and G. S. Stewart. 2009. Dietary regulation of ruminal bUT-B urea transporter expression and localization. J. Anim. Sci. 87:3288-3299.

Stewart, G. S., C. Graham, S. Cattell, T. P. L. Smith, N. L. Simmons, and C. P. Smith. 2005. UT-B is expressed in bovine rumen: Potential role in ruminal urea transport. Am. J. Physiol. Regul. Integr. Comp. Physiol. 289:R605-R612.

Stewart, G. S., and C. P. Smith. 2005. Urea nitrogen salvage mechanisms and their relevance to ruminants, non-ruminants and man. Nutr. Res. Rev. 18:49-62.

Sunny, N. E., S. L. Owens, R. L. Baldwin VI, S. W. El-Kadi, R. A. Kohn, and B. J. Bequette. 2007. Salvage of blood urea nitrogen in sheep is highly dependent upon plasma urea concentration and the efficiency of capture within the digestive tract. J. Anim. Sci. 85:1006-1013.
Taniguchi, K., G. B. Huntington, and B. P. Glenn. 1995. Net nutrient flux by visceral tissues of beef steers given abomasal and ruminal infusions of casein and starch. J. Anim. Sci. 73:236-249.

Vagnoni, D. B., G. A. Broderick, M. K. Clayton, and R. D. Hatfield. 1997. Excretion of purine derivatives by holstein cows abomasally infused with incremental amounts of purines. J. Dairy Sci. 80:1695-1702.

Wallace, R. J., K.-J. Cheng, D. Dinsdale, and E. R. Ørskov. 1979. An independent microflora of the epithelium and its role in the ecomicrobiology of the rumen. Nature 279:424-426.

Wickersham, T. A., E. C. Titgemeyer, R. C. Cochran, E. E. Wickersham, and D. P. Gnad. 2008. Effect of rumen-degradable intake protein supplementation on urea kinetics and microbial use of recycled urea in steers consuming low-quality forage. J. Anim. Sci. 86:3079-3088 